\title{
The cultivation of five microalgae species and their potential for biodiesel production
}

\author{
Mónica Cristina Rodríguez-Palacio ${ }^{1,2^{*}}$ (D), René Bernardo Elías Cabrera-Cruz ${ }^{1}$, Julio Cesar Rolón-Aguilar ${ }^{1}$, \\ Ricardo Tobías-Jaramillo ${ }^{1}$, Marisol Martínez-Hernández ${ }^{2}$ and Cruz Lozano-Ramírez ${ }^{2}$
}

\begin{abstract}
Background: Due to the problems we face today, such as wastewater pollution of aquifers and climate change, it is necessary to search for environmental solutions that help us minimize this problem. An alternative solution might be the cultivation of microalgae that are efficient in the purification of wastewater, removal of greenhouse gases and production of biomass that can be used for the production of biofuels such as biodiesel, methane, bioethanol, among others. The aim of this work is to cultivate five strains of microalgae native in Mexico: Chlorella miniata, Coelastrella sp., Desmodesmus quadricauda, Neochloris oleoabundans and Verrucodesmus verrucosus. The cultivations were performed using municipal wastewater and a foliar fertilizer with the further purpose of assessing their capacity to produce various types of biomass, in particular lipids.

Methods: The experiments were carried out using triplicate 16-L glass bioreactors assays with a 12:12 light-darkness cycle at $25^{\circ} \mathrm{C} \pm 1$ under constant aeration. Every 3rd day, a 1-mL sample was taken to determine cell density. In the stationary growth phase, each culture was harvested by sedimentation and lipid content analysis was performed. The biomass with the highest concentration of total lipids was subjected to an analysis of the methyl esters of fatty acids.

Results: An ANOVA test showed significant differences between the growth rates ( $F=6.8, p=0.0001)$. The species that were able to produce biomass with the highest concentrations of total lipids were Coelastrella sp. with 44-46\%; Verrucodesmus verrucosus with $43-44 \%$ and Neochloris oleoabundans 35-37\%. As the analysis of the methyl esters of fatty acids showed, the species Coelastrella sp. and $V$. verrucosus produced lipids composed of $82.9 \%$ and $91.28 \%$ of fatty acids, respectively, containing C16-C18 carbon chains.
\end{abstract}

Conclusions: All the species used in the present study were able to grow on wastewater and produce high concentrations of lipids. Therefore, the demands for biodiesel production could be met in the immediate future after continuing working with different microalgae species. Therefore, it is necessary to determine their adaptation potential to grow on contaminated effluents and produce lipids that can be used for the benefit of people and environment.

Keywords: Phycoremediation, Wastewater treatment with microalgae, Biodiesel from microalgae, Verrucodesmus verrucosus, Coelastrella sp.

\footnotetext{
*Correspondence: mony@xanum.uam.mx

${ }^{1}$ Division of Graduated Studies and Research, Faculty of Engineering

"Arturo Narro Siller", Autonomous University of Tamaulipas, Ciudad Victoria, Tamaulipas, Mexico

Full list of author information is available at the end of the article
}

\begin{abstract}
Background
The accumulation of organic pollutants in aquatic ecosystems causes adverse effects on human health and environment. These pollutants are introduced as a result of human activities involving industrial, domestic, livestock and agricultural discharges. As pollution problems increase, research with microorganisms is progressing in order to degrade or neutralize organic pollutants in
\end{abstract}

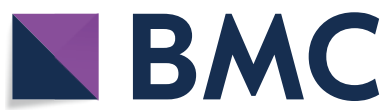

(c) The Author(s) 2022. Open Access This article is licensed under a Creative Commons Attribution 4.0 International License, which permits use, sharing, adaptation, distribution and reproduction in any medium or format, as long as you give appropriate credit to the original author(s) and the source, provide a link to the Creative Commons licence, and indicate if changes were made. The images or other third party material in this article are included in the article's Creative Commons licence, unless indicated otherwise in a credit line to the material. If material is not included in the article's Creative Commons licence and your intended use is not permitted by statutory regulation or exceeds the permitted use, you will need to obtain permission directly from the copyright holder. To view a copy of this licence, visit http://creativecommons.org/licenses/by/4.0/. The Creative Commons Public Domain Dedication waiver (http://creativeco mmons.org/publicdomain/zero/1.0/) applies to the data made available in this article, unless otherwise stated in a credit line to the data. 
aquatic systems $[1,2]$. Bioremediation is the process by which pollutants are removed from the environment by using organisms or parts of them, and as a result, the pollutants are removed or reduced or as in our case, degraded to simple compounds. This new technology is much cheaper and more environmentally friendly than other ones and is very promising for large-scale problem solving $[1,3]$.

The principle of cultivation of microalgae used in this study could be compared to that of a biorefinery because it allows for producing many products with a high added value. Industrial production is however, limited by the costs of mineral salts and other nutrients needed for cultivation. Therefore, it is important to keep in mind that wastewater can be a potential culture medium for cultivating these microorganisms due to many "collateral" benefits such as biological treatment of polluted water, production of biomass and biofuels [2, 3].

In 2014, the International Energy Agency reported that $63.7 \%$ of the oil produced is consumed by the transport sector, which is equivalent to $22 \%$ of the global $\mathrm{CO}_{2}$ emissions [4]. Therefore, research and development of biofuels has regained importance and those currently under development are biodiesel, produced by the reaction of vegetable oils or animal fats with alcohol; bioethanol produced by the fermentation of organic matter with high starch content and biogas composed mainly of methane, formed by the degradation of organic matter $[5,6]$.

The biofuels produced are classified according to the raw materials used into first, second and third-generation fuels. The first-generation biofuels are obtained from natural resources from agriculture and food generation, for example, palm, corn, cane, soy, wheat, sunflower. The second-generation biofuels are those produced, for example, from grass, wood, lignocellulosic waste, food waste, and inedible plant crops such as Ricinus communis and Jatropha curcas. These biofuels might cause problems of deforestation, introduction of invasive species and pests and might threaten biodiversity, compete on land that can be used for food production and are therefore not suitable to fulfill the demand for sustainability [ 4 , $7,8]$.

Microalgae and cyanobacteria are considered thirdgeneration biofuel producers. In relation to photosynthesis, they are highly efficient and excellent biomass producers. Moreover, they can be employed in nonfertile soils, or can use wastewater or brackish water for producing high amounts of lipids. Likewise, they are very good $\mathrm{CO}_{2}$ fixers $[4,8]$.

A great deal of effort has been made in microalgae biotechnology regarding the treatment of wastewater. This is due to the capacity of adaptation of these microorganisms to this type of effluents, seen in their rapid growth and capacity to remove nutrients. More than 50 years ago Caldwell [9] and later Oswald et al. [10] suggested the use of massive microalgae cultures for wastewater treatment and protein production simultaneously. Recently, however, this has become more relevant, due to problems of pollution, climate change, population growth, increasing discharges of untreated wastewater and decreasing numbers of clean or pristine water bodies.

Microalgae can be used for tertiary wastewater treatment to achieve better effluent quality through a low energy cost mechanism, where nutrients that were being discharged are nowadays be utilized and metabolized to biomass of high commercial value. According to its chemical composition, this biomass can become a source of fertilizers as well as energy in the first instance [3, 11-13].

Lipids, the raw material for the production of biofuels, are one of the main components of microalgae biomass and their concentrations fluctuate between 20 and 50\% of the dry weight depending on each species. The concentration of lipids is also dependent on light intensity, temperature, carbon dioxide concentration and nitrogen presence. However, an important factor for the overall success of biofuel production is the selection of the microalgae strain that should perform optimally in the production of algal biomass and be able to accumulate triacylglycerides and adapt to extreme environments, among others [2, 4, 14, 15]. For this reason, we decided to work with five species of freshwater green microalgae (among them were also were those, not have been used in phytoremediation processes until now) and to cultivate them in raw municipal wastewater for testing their adaptation to a complex environment and studying the potential of their biomass for biodiesel production.

\section{Methods}

The microalgae chosen in the present work were: Chlorella miniata, Coelastrella sp., Desmodesmus quadricauda, Neochloris oleoabundans, Verrucodesmus verrucosus. These strains belong to the microalgae culture collection of the Applied Phycology Laboratory at UAM Iztapalapa, México (Fig. 1).

These microalgae were selected due to previous studies where they showed rapid growth and accumulation of lipids, when cultivated on conventional culture media $\mathrm{F} / 2[11,16]$ and in the foliar fertilizer Bayfolan forte [3].

All microalgae were evaluated in batches in triplicate where a $20 \%(\mathrm{v} / \mathrm{v})$ inoculum was taken from exponential phase cultures. The growth of each microalga was maintained in 16-L glass photobioreactors with aeration through injection pumps in a range of $0.6 \mathrm{vvm}$ (volume of air per total volume of the bioreactor per minute) and at an irradiance of $50 \mathrm{mmol} / \mathrm{m}^{2} / \mathrm{s}$. The experiments were 


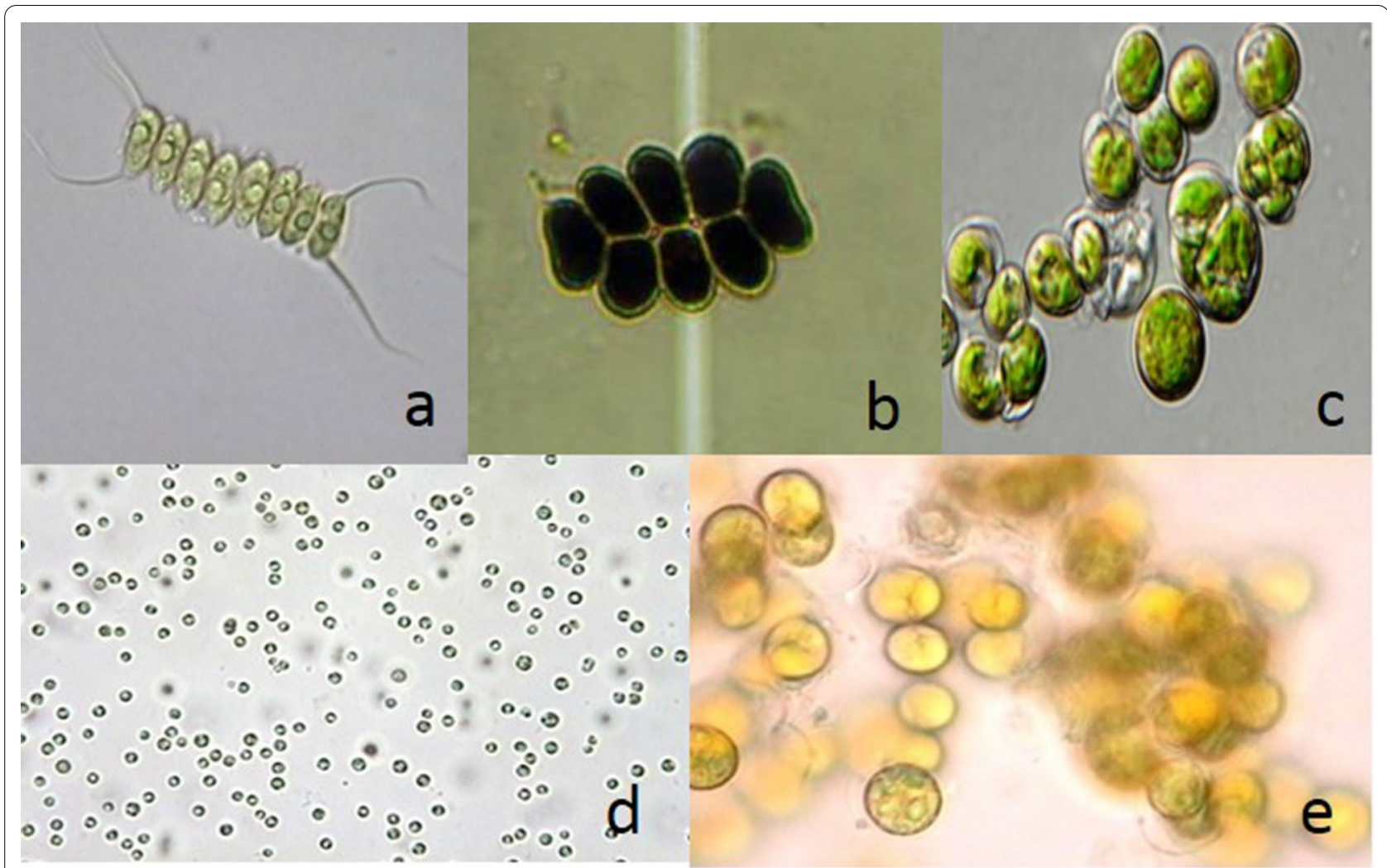

Fig. 1 Optical microphotographies of the species used in the present study: a Desmodesmus quadricauda, b Verrucodesmus verrucosus, c Neochloris oleoabundans, d Chlorella miniata, e Coelastrella sp

Table 1 Bayfolan forte culture medium (BF)

\begin{tabular}{llll}
\hline Compound & $\%(\mathbf{p} / \mathbf{v})$ & Compound & $\%(\mathbf{p} / \mathbf{v})$ \\
\hline Total nitrogen $(\mathrm{N})$ & 11.470 & $\begin{array}{l}\text { Phosphorous } \\
\text { Oxide }\left(\mathrm{P}_{2} \mathrm{O}_{5}\right)\end{array}$ & 8.000 \\
Potassium oxide $\left(\mathrm{K}_{2} \mathrm{O}\right)$ & 6.000 & Boron $(\mathrm{B})$ & 0.036 \\
Copper $(\mathrm{Cu})$ & 0.040 & Iron $(\mathrm{Fe})$ & 0.050 \\
Molybdenum $(\mathrm{Mo})$ & 0.005 & Zinc $(\mathrm{Zn})$ & 0.080 \\
Thiamine hydrochloride & 0.004 & Sulfur $(\mathrm{S})$ & 0.230 \\
Calcium oxide $(\mathrm{CaO})$ & 0.025 & Cobalt $(\mathrm{Co})$ & 0.002
\end{tabular}

One milliliter of Bayfolan Forte was added to $1 \mathrm{~L}$ of distilled water

carried out for 30-60 days and the algal biomass was subsequently harvested. For harvesting, aeration of the reactors was suspended and the cultures were placed in a refrigerator at $4{ }^{\circ} \mathrm{C}$ to accelerate algal sedimentation.

The growth of each microalgae strain was monitored every third day by using a Neubauer camera with an optical microscope [16].

The following culture media were used: leaf fertilizer Bayfolan Forte $\odot$ (Table 1) and municipal wastewater.

The samples of treated municipal water were collected from an anaerobic UASB reactor (Experimental Pilot
Table 2 Composition of the culture medium

\begin{tabular}{lll}
\hline Culture medium & \multicolumn{2}{l}{ Nutrient concentrations } \\
\cline { 2 - 3 } & $\mathbf{N}-\left[\mathrm{NH}_{\mathbf{4}}\right]$ & $\mathbf{P}-\left[\mathrm{PO}_{\mathbf{4}}{ }^{-\mathbf{3}}\right]$ \\
\hline Bayfolan forte & 11.47 & 8.0 \\
Wastewater & 22.0 & 8.0 \\
\hline
\end{tabular}

Plant No. 9 of the UAM-I), where the levels of ammonium concentration ranged from 20.5 to $40.8 \mathrm{mg} / \mathrm{L}$ and the orthophosphates ranged from 4.9 to $16.5 \mathrm{mg} / \mathrm{L}$ [3]. The samples were irradiated with UV light for a period of $48 \mathrm{~h}$, and for all the experiments this effluent treated at $100 \%(\mathrm{v} / \mathrm{v})$ was used. The final composition of this culture medium is shown in Table 2.

The percentage of lipids was determined by the method proposed by Bligh and Dyer [17]. The results obtained were subjected to an analysis of variance (ANOVA) in order to evaluate the differences in the treatment. The statistical program SYSTAT 9 was used. The resulting total lipids and the profiles of the methyl esters of fatty acids (FAMEs) were analyzed in a gas chromatograph with a flame ionization detector (FID) (HP6890) [18]. 
Table 3 Maximum cell growth and harvested biomass in the different culture media

\begin{tabular}{lllllll}
\hline Days & Microalgae & \multicolumn{2}{l}{ Cells $/ \mathbf{m L}$} & & gr/L & \\
\cline { 3 - 4 } & & WW & BF & & WW & BF \\
\hline 21 & V.verrucosus & $93 \times 10^{6}$ & $95 \times 10^{6}$ & 4 & 4.3 \\
26 & Coelastrella sp. & $50 \times 10^{6}$ & $52 \times 10^{6}$ & 3 & 3.2 \\
53 & N. oleoabundans & $45 \times 10^{5}$ & $47 \times 10^{5}$ & 2.8 & 2.9 \\
59 & C. miniata & $20 \times 10^{5}$ & $25 \times 10^{5}$ & & 1 & 1.1 \\
59 & D. quadricauda & $59 \times 10^{5}$ & $66 \times 10^{5}$ & & 3.2 & 3.5 \\
\hline
\end{tabular}

Table 4 Lipid content of the biomass cultivated in WW and BF

\begin{tabular}{lll}
\hline Microalgae species & WW & BF \\
\hline Chlorella miniata & 27.3 & 25.5 \\
Coelastrella sp. & 46.9 & 44.6 \\
Desmodesmus quadricauda & 26.5 & 25.3 \\
Neochloris oleoabundans & 37.3 & 35.5 \\
Verrucodesmus verrucosus & 44.6 & 43.5 \\
\hline
\end{tabular}

\section{Results and discussion}

The cultures did not reach maximum cell growth at the same time, after 21 days, Verrucodesmus verrucosus reached maximum growth, followed at 25 days by Coelastrella sp. (Table 3).

Using the cell growth data for every species, a nonparametric Kruskal-Wallis ANOVA test was performed resulting in a value of $p=0.003^{<} \lambda=0.05$, and the analysis of multiple comparisons showed significant differences between Coelastrella sp. and Verrucodesmus verrucosus compared to all other species.

According to the statistical analysis of the variance (ANOVA) the results regarding the lipid content produced by the strains cultivated in foliar fertilizer (BF) and on municipal wastewater (WW) (Table 4) were not found significantly different $(p=\leq 0.05)$.

The species generated the highest concentration of total lipids were Coelastrella sp. with 44-46\%; V. verrucosus with $43-44 \%$ and $N$. oleoabundans $35-37 \%$. The Neochloris species were extensively studied for their ability to accumulate lipids in conventional culture media. Lipid concentrations between 35 and 54\% and 46.1 and $57.7 \%$ were reported for these species [7]. It should however be noted that these concentrations were achieved using ideal culture media, and not on municipal wastewater. Recently, it has been reported about the potential of $V$. verrucosus, not only to store lipids, but also to bioremediate pollutant effluents such as organic leachate and wastewater [19-21] Coelastrella sp. is a species that has a high potential to accumulate lipids and other bioproducts such as betacarotenes [22, 23]. The percentages of lipids produced reached 46.9 and $44.6 \%$, and were higher than those reported by Luo et al. [24], who achieved values of $22.4 \%$ and 25.5\%; and Dimitrova et al. [22], who reported a percentage of $37 \%$ [22].

For the species which produced the highest percentages of total lipids, we performed an analysis of fatty acids to determine their potential for biodiesel production. As we know, the main components of the lipid fraction are triacylglycerols, free fatty acids, waxes, sterols, hydrocarbons, glycolipids (predominant in chloroplastic membranes), phospholipids (abundant in plasmalemma and diverse endomembranous systems) and pigments (carotenoids, chlorophylls, phycobilins, etc.) [16, 25-27]. Not all microalgal lipids are suitable for biodiesel production, however, the appropriate ones (fatty acids, free and covalently bound to glycerol and its derivatives) are frequently produced and constitute the largest fraction of total lipids, usually from 20 to $40 \%[7,25]$.

According to the results, the total lipids of Verrucodesmus verrucosus are composed of $91.28 \%$ of fatty acids with $\mathrm{C} 16-\mathrm{C} 18$ carbon chains that are highly recommendable for the production of biodiesel [28], whereas the percentage of linoleic acid $(\mathrm{C} 18: 3)$ is below $12 \%$, which meets the quality standards for fatty acids precursors of biodiesel (Fig. 2) [29].

When Coelastrella sp. is used, the total lipids are composed of $82.9 \%$ fatty acids with $\mathrm{C} 16-\mathrm{C} 18$ carbon chains, the percentage of $\mathrm{C} 18: 3$ is less than $12 \%$ which makes the biomass of this microalgae species also suitable for biodiesel synthesis (Fig. 2).

Figure 2 depicts the result of Neochloris oleoabundans, where an increase in fatty acids with unsaturated chains (C18:2) is observed and, in the case of C18:3 its percentage exceeds the limit of $12 \%$ which is a disadvantage in terms of the quality criteria established by law, although there was no presence of polyunsaturated fatty acids (presence of 4 or more double bonds in the chains). The high percentage of $\mathrm{C} 18: 3$ makes the biomass unsuitable for producing biodiesel (Fig. 2). It is worth mentioning that the presence of double bonds in fatty acid chains affects the quality of biodiesel, making its chemical structure more reactive to free radicals [29].

\section{Conclusions}

All species used in the present study were able to grow on wastewater and produce high concentrations of lipids, above 25\%. Among them the Coelastrella sp., Verrucodesmus verrucosus and Neochloris oleoabundans species showed better results than the others. Therefore, the first two species are good candidates for the production of biodiesel due to their fatty acids type produced and the amount of biomass obtained in less time. 


\section{0}

FAME'S

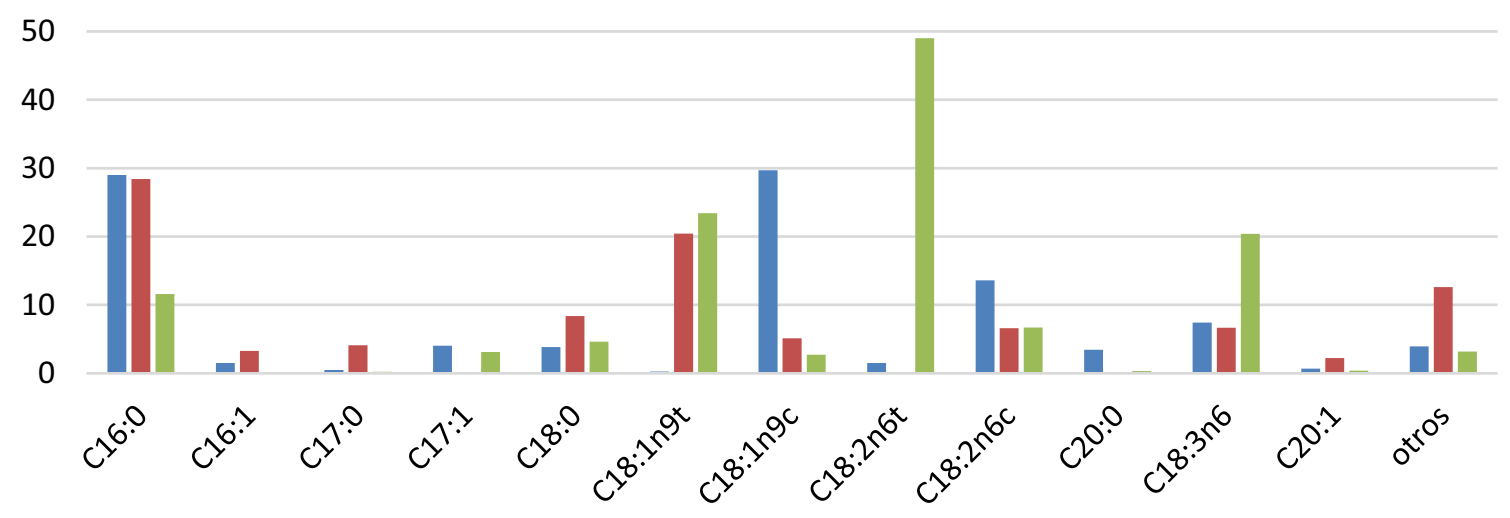

\section{Verrucodesmus Coelastrella $\square$ Neochloris}

Fig. 2 Comparison of the FAMEs profile of the three species

It is necessary to continue working on a laboratory and pilot scale with native and little studied species, such as those used in the present study, in order to determine their potential of adaptation to growth on contaminated effluents and to evaluate the total lipid production. These sustainable energetic and ecological alternatives should to be implemented during a largescale cultivation in the near future to achieve virtuous production circles, such as cleaning a polluted effluent, capturing greenhouse gases and producing biomass that can be used for the production of biodiesel or other value-added bioproducts.

\section{Abbreviations}

BF: Bayfolan forte media; WW: Wastewater; FAMES: Fatty acid methyl esters; ANOVA: Analysis of variance.

\section{Acknowledgements}

The authors are grateful to the Autonomous University of Tamaulipas, Faculty of Engineering "Arturo Narro Siller", Division of Graduated Studies and Research for participating in the Project "Microalgae Cultivation, Potential Uses. Caribbean and Gulf of Mexico". Autonomous Metropolitan University.

\section{Authors' contributions}

All sections of the study, including concepts, experimental design and laboratory work, were conducted with the participation of the authors. All authors contributed to the conclusions, the summary and the perspective of the study. All authors read and approved the final manuscript.

\section{Funding}

The study was financed by the authors, under the auspices of the Department of Hydrobiology of the Autonomous Metropolitan University and the Doctorate in Environment of the Faculty of Engineering "Arturo Narro Siller" of the Tamaulipas Autonomous University, Mexico.
Availability of data and materials

Data and additional materials are available on request.

\section{Declarations}

Ethics approval and consent to participate

The authors declare that they complied with the ethical guidelines.

\section{Consent for publication}

The authors declare that they give consent for publication.

\section{Competing interests}

The authors declare that they have no competing interests.

\section{Author details}

${ }^{1}$ Division of Graduated Studies and Research, Faculty of Engineering "Arturo Narro Siller", Autonomous University of Tamaulipas, Ciudad Victoria, Tamaulipas, Mexico. ${ }^{2}$ Applied Phycology Laboratory, Hydrobiology Department, Metropolitan Autonomous University, P.O.B. 55-535, 09340 Mexico City, Mexico.

Received: 1 June 2019 Accepted: 6 February 2022

Published online: 15 February 2022

\section{References}

1. Chekroun KB, Sánchez E, Baghour M (2014) Int Res J Public Environ Health. 1(2):19-32. http://www.journalissues.org/irjpeh.

2. Hong-Wei Y, Chen Hul, Chun-Yen C, Shih-Hsin H, Duu-Jong L, Jo-Shu C (2013) Microalgae-based biorefinery-from biofuels to natural products. Bioresource Technol 135:166-174

3. Rodríquez-Palacio MC, Cabrera Cruz RBE, Rolón Aguilar JC, Lozano Ramírez C, Galeana Hurtado LJ, Morales Avendaño ED (2018) Comparative study on the removal of $\mathrm{N}$ and $\mathrm{P}$ from municipal waste waters and leached vermicomposting using five microalgae strains. Desalin Water Treat 131:180-186. https://doi.org/10.5004/dwt.2018.23035

4. Arenas EG, Rodríguez-Palacio MC, Juantorena AU, Sebastian PJ (2017) Microalgae as a potential source for biodiesel production: techniques, 
methods and other challenges. Int J Energy Res 41(6):761-789. https:// doi.org/10.1002/er.3663

5. Milledge JJ (2011) Comercial application of microalgae other that as biofuels: a brief review. Rev Environ Sci Biotechnol 10:31-41

6. Serna F, Barrera L, Montiel H (2011) Impacto Social y Económico en el Uso de biocombustibles. J Technol Manag Innov 6(1):100-114

7. Meng X, Yang J, Xu X, Zhang L, Nie Q, Xian M (2009) Biodiesel production from oleaginous microorganisms. Renew Energy 34:1-5

8. Huang G, Chen F, Wei D, Zhang XW, Chen G (2010) Biodiesel production by microalgal biotechnology. Appl Energy 87:38-46

9. Caldwell DH (1946) Sewage oxidation pond performance, operation and design. Sewage Works J 3:433-458

10. Oswald WJ, Gotaas HB, Ludwig HF, Lynch V (1953) Algae symbiosis in oxidation ponds. III. Photosynthetic Oxygenation. Sewage Ind Wastes 25(6):692-705. http://www.jstor.org/stable/25032197. Accessed 31 Jan 2021

11. Richmond A, Qiang H (2013) Handbook of microalgal culture: applied phycology and biotechnology, 2nd edn. Wiley-Blackwell, Hoboken, p 736

12. Hernández Reyes BM, Rodríguez-Palacio MC, Lozano-Ramírez C, CastillaHernández P (2012) Remoción de nutrientes por tres cultivos de microalgas libres e inmovilizados. Revista Latinoamericana de Biotecnología Algal y Ambiental 3(1):80-94. http://www.solabiaa.org/ojs3/index.php/ RELBAA/article/view/35.

13. Vanthoor-Koopmans M, Cordoba-Matson MV, Arredondo-Vega BO, Lozano-Ramírez C, García Trejo JF, Rodríguez-Palacio MC (2014) Chapter 8 : Microalgae and cyanobacteria production for food and food supplements. In: Guevara-Gonzalez R, Torres-Pacheco I (eds) Biosystems engineering: biofactories for food production in XXI century, No. 8. Springer, Berlin, pp 253-275

14. Mata TM, Martins A, Caetano NS (2010) Microalgae for biodiesel production and other applications: a review. Renew Sustain Energy Rev $14: 217-232$

15. Rodolfi L, Zitelli GC, Bassi N, Padovani G, Biondi N, Bonini G, Tredici MR (2009) Microalgae for oil: strain selection, induction of lipid synthesis and outdoor mass cultivation in a low-cost photobioreactor. Biotechnol Bioeng 102(1):100-112

16. Becker EW (1994) Microalgae: biotechnology and microbiology. Cambridge University Press, Cambridge, p 293

17. Bligh GE, Dyer JW (1959) A rapid method of total lipid extraction and purification. Can J Biochem Physiol 37(3):911-917

18. Toledo-Cervantes A, Morales M, Novelo E, Revash S (2013) Carbon dioxide fixation and lipid storage by Scenedesmus obtusciusculus. Bioresour Technol 130:652-658

19. Beal CM, Webber ME, Ruoff RS, Hebner RE (2010) Lipid analysis of Neochloris oleoabundans by liquid state NMR. Biotechnol Bioenergy 106(4):573-583

20. Arenas EG, Rodríguez-Palacio MC, Juantorena AU, Aranda VD, Nava FMA, Sebastian PJ (2017) Dual role of Verrucodesmus verrucosus for residual effluents treatment and lipid production for biodiesel. In: The 7th international conference on algal biomass, biofuels and bioproducts. Miami, FL, USA

21. Arenas EG, Rodríguez-Palacio MC, Juantorena AU, Sebastian PJ (2016) GCMS and FTIR spectroscopic determination of lipids and fatty acid profile of microalgae Verrucodesmus verrucosus under different residual culture media. In: The 6th international conference on algal biomass, biofuels and bioproducts. Paradise Point, San Diego, USA

22. Dimitrova P, Marinova G, Alexandrov S, Iliev I, Pilarski P (2017) Biochemical characteristics of a newly isolated strain Coelastrella sp. BGV cultivated at different temperatures and light intensities. Annuaire de L'Université de Sofía "St. Kliment Ohridski" Faculte de Biologie 102(4):139-146

23. Iyer G, Nagle V, Gupte YV, Desai S, Iyer M, Moramkar N, Sawant V (2015) Characterization of high carotenoid producing Coelastrella oocystiformis and its anti-cancer potential. Int J Curr Microbiol Appl Sci 4(10):527-536

24. Luo L, He H, Yang C, Wen S, Zeng G, Wu M, Zhou Z, Lou W (2016) Nutrient removal and lipid production by Coelastrella sp. in anaerobically and aerobically treated swine wastewater. Bioresour Technol 216:135-141

25. Cohen Z (2004) Products from microalgae. In: Richmond A (ed) Handbook of microalgal mass culture. CRC Press, Boca Raton, pp 421-454

26. Guschina IA, Harwood L (2006) Lipids and lipid metabolism in eukaryotic algae. Prog Lipid Res 45:160-186
27. Hu CW, Chuang LT, Yu PC, Chen CNN (2013) Pigment production by a new thermotolerant microalga Coelastrella sp F50. Food Chem 138(4):2071-2078

28. Knothe $G$ (2009) Improving biodiesel fuel properties by modifying fatty ester composition. Energy Environ Sci 2:759-766

29. MontesD'Oca MC, Viêgas CV, Lemõesa JS, Miyasaki EK, Morón-Villarreyes JA, Primel EG, Abreu PC (2011) Production of FAMEs from several microalgal lipidic extracts and direct transesterification of the Chlorella pyrenoidosa. Biomass Bioenerg 35(4):1533-1538

\section{Publisher's Note}

Springer Nature remains neutral with regard to jurisdictional claims in published maps and institutional affiliations.

Ready to submit your research? Choose BMC and benefit from:

- fast, convenient online submission

- thorough peer review by experienced researchers in your field

- rapid publication on acceptance

- support for research data, including large and complex data types

- gold Open Access which fosters wider collaboration and increased citations

- maximum visibility for your research: over $100 \mathrm{M}$ website views per year

At BMC, research is always in progress.

Learn more biomedcentral.com/submissions 